\title{
電解コンデンサー陽極用高純度アルミの誘電 体皮膜に関する研究
}

\author{
（第4報）微量の Fe, Si， Cu の静電容量に及ぼす影響
}

\section{川島浪夫* 中村雄 造**西坂 基***}

Study on formation of dielectric film of super-purity aluminium in electrolytic condenser (UDC 669.718.91:621.317.335)

4 th Report: Effect of small amount of Si, Fe or $\mathrm{Cu}$ on Electostatic capacity KAWASHIMA Namio* NAKAMURA Yuzo** NISHIZAKA Motoi***

It is generally known that $99.990-99.992 \%$ aluminium with an impurity of $0.002-0.004 \%$ iron intentionally added is superior to $99.993-98.998 \%$ aluminium for making the grain finer and the electrostatic capacity greater.

The purpose of the experiment was to investigate the influences of small amounts of impurities usually contained in the $99.99 \%$ aluminium, such as iron, silicon, or copper, on its electrostatic capacity.

As a result, we realized that it was more desirable for greater electrostatic capacity to use copper, than to use rather harmful iron intentionally.

Hence it is said that the $99.993-99.8 \%$ aluminium foil, containing the impurities of limited amount of $0.007-0.009 \% \mathrm{Si}$, less than $0.001 \% \mathrm{Fe}$, or $0.00-0.003 \% \mathrm{Cu}$, is far superior to those on the free market as anode material for greater electrostatic capacity.

(Received Oct. 1, 1956)

\section{1. 緒言}

最近ますますテレビ、レーダー等の電子管機器の発達 に伴い電解コンデンサーの需要は急激に伸びており、大 容量小型のものが要求されているし、然も耐圧性に優れ 漏洩電流の䒼少なることが必要である。それには陽極用 アルミ箔の単位寸法当りの静電容量の高いもの、即ち化 成前のエツチングによる表面拡大率の大なる材料でなけ ればならない。

著者等は第 1 報、第 2 報、第 3 報に於て純度の影響、 各種不純物の化成性能（化成所要時間及び漏洩電流）に 及ほす影響、更に $\mathrm{Ca}, \mathrm{Zr}, \mathrm{Mg}, \mathrm{Zn}$. 等の化成性能及 び静電容量に及ぼす影響に関して詳細に報告したが、今 回は 99.99\% $\mathrm{Al}$ に含まれる主なる不純物である $\mathrm{Fe}, \mathrm{Si}$ ， $\mathrm{Cu}$ の微量含有量（各 $0.010 \%$ 以下）の静電容量に及ぼ す影響に関し実験を行い、現在実用されている $99.99 \%$ Al 䇴よりも一層優秀な化成性能を有し更により高静電
容量が得られる材料を得んとするものである。

\section{2. 試料}

試験に用いた各試料は $3 \mathrm{~kg}$ 小型スラブを調質加熱後、 冷間圧延し長さ $6 \mathrm{~m}$ 及び $1 \mathrm{~mm}$ 厚で 2 回中間焼鈍を 行い $0.1 \mathrm{~mm}$ 䇴にしたもので最終圧延率は90\%である。 各試料の化学分析の結果は Table 1 に示す。

\section{3. 試 験 方 法}

電気炉にて軟化した $0.1 \mathrm{~mm}$ の簿を $45 \times 90 \mathrm{~mm}^{2}$ に切 出し軽く縁を折り曲げて $85 \sim 90^{\circ} \mathrm{C}$ の $\mathrm{Na}_{2} \mathrm{CO}_{3} 1 \%$ の水 溶液中にて $10 \mathrm{sec}$ 間洗滌して水洗する。これを混酸水 溶液 $\left(\mathrm{HCl} 35 \%, \mathrm{H}_{2} \mathrm{SO}_{4} 5 \%, 35^{\circ} \pm 1{ }^{\circ} \mathrm{C}\right)$ 中に浸漬し て電気密度 $60 \mathrm{~A} / \mathrm{dm}^{2}$ をるつて最初交流で、続いて直 流にて $3 \sim 4 \mathrm{~min}$ 間電解腐食を行つた。その際の腐食 減量は25\%一定になるようにした。

腐食を終つた試料は $50 \% \mathrm{HNO}_{3}$ 水溶液に浸漬後流水

\section{* 東洋アルミニウム(株)工場長 工博 \\ ** 技術課工博 \\ *** 技術課}

* Toyo Aluminium Co., Ltd. ** Ditto *** Ditto 
Table 1 Chemical Composition of Specimens

\begin{tabular}{|c|c|c|c|c|c|}
\hline \multirow{2}{*}{ 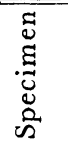 } & \multicolumn{4}{|c|}{ Chemical composition (\%) } & \multirow{2}{*}{ 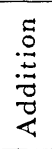 } \\
\hline & $\mathrm{Al}$ & $\mathrm{Si}$ & $\mathrm{Fe}$ & $\mathrm{Cu}$ & \\
\hline $\begin{array}{ll}F & 2 \\
F & 3 \\
F & 4 \\
F & 6\end{array}$ & $\begin{array}{l}99.992 \\
99.990 \\
99.990 \\
99.988\end{array}$ & $\begin{array}{l}0.005 \\
0.005 \\
0.005 \\
0.005\end{array}$ & $\begin{array}{l}0.002 \\
0.003 \\
0.004 \\
0.006\end{array}$ & $\begin{array}{l}0.001 \\
0.002 \\
0.001 \\
0.001\end{array}$ & $\mathrm{Fe}$ \\
\hline $\begin{array}{l}\text { S } 13 \\
\text { S } 14 \\
\text { S } 16 \\
\text { S } 18\end{array}$ & $\begin{array}{l}99.995 \\
99.993 \\
99.992 \\
99.990\end{array}$ & $\begin{array}{l}0.003 \\
0.004 \\
0.006 \\
0.008\end{array}$ & $\begin{array}{l}0.001 \\
0.001 \\
0.001 \\
0.001\end{array}$ & $\begin{array}{l}0.001 \\
0.002 \\
0.001 \\
0.001\end{array}$ & $\mathrm{Si}$ \\
\hline $\begin{array}{l}\text { S } 23 \\
\text { S } 24 \\
\text { S } 26 \\
\text { S } 28\end{array}$ & $\begin{array}{l}99.994 \\
99.993 \\
99.992 \\
99.990\end{array}$ & $\begin{array}{l}0.003 \\
0.004 \\
0.006 \\
0.008\end{array}$ & $\begin{array}{l}0.002 \\
0.002 \\
0.002 \\
0.002\end{array}$ & $\begin{array}{l}0.001 \\
0.001 \\
\operatorname{tr} \\
\operatorname{tr}\end{array}$ & $\mathrm{Si}$ \\
\hline $\begin{array}{l}\text { S 33 } \\
\text { S 34 } \\
\text { S 36 } \\
\text { S } 38\end{array}$ & $\begin{array}{l}99.994 \\
99.992 \\
99.990 \\
99.988\end{array}$ & $\begin{array}{l}0.003 \\
0.004 \\
0.006 \\
0.008\end{array}$ & $\begin{array}{l}0.003 \\
0.003 \\
0.003 \\
0.003\end{array}$ & \begin{tabular}{l|}
$\operatorname{tr}$ \\
0.001 \\
0.001 \\
0.001
\end{tabular} & $\mathrm{Si}$ \\
\hline $\begin{array}{ll}\text { C } & 1 \\
\text { C } & 2 \\
\text { C } & 3 \\
\text { C } & 4\end{array}$ & $\begin{array}{l}99.993 \\
99.993 \\
99.991 \\
99.991\end{array}$ & $\begin{array}{l}0.004 \\
0.004 \\
0.004 \\
0.004\end{array}$ & $\begin{array}{l}0.002 \\
0.001 \\
0.002 \\
0.001\end{array}$ & $\begin{array}{l}0.001 \\
0.002 \\
0.003 \\
0.004\end{array}$ & $\mathrm{Cu}$ \\
\hline
\end{tabular}

中にて水洗し、次いで蒸溜水にて洗滌乾燥した。これよ り $25 \times 50 \mathrm{~mm}^{2}$ の矩形に柄のついた庖丁形に試料を切出 し蒸溜水中にて $10 \mathrm{~min}$ 間惹沸して取出して $40 \pm 70^{\circ} \mathrm{C}$ に保つた $5 \%$ 蕯酸水溶液中で A. C. $30 \mathrm{~V} に 5 \mathrm{~min}$ 間 予備化成を行つて洗涤し続いて冷却装置を付した $0.4 \%$ 硼酸アンモン水溶液中で D. C. $120 \mathrm{~mA} / \mathrm{dm}^{2}$ の電流密 度で $450 \mathrm{~V}$ 迄主化成を行い、その電圧に $10 \mathrm{~min}$ 間保持 後直に $20 \pm 1 \circ$ の $2 \%$ 嗍酸アンモン水溶液中に移し横河 製万能インピーダンスブリツジを用い偏偷電圧 $6 \mathrm{~V} \cdot$ 一゙

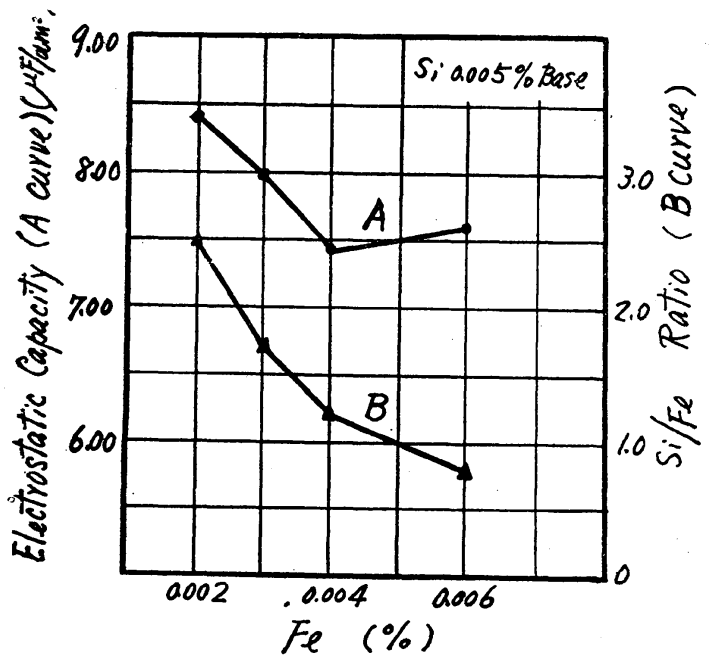

Fig. 1 Effect of $\mathrm{Fe}$

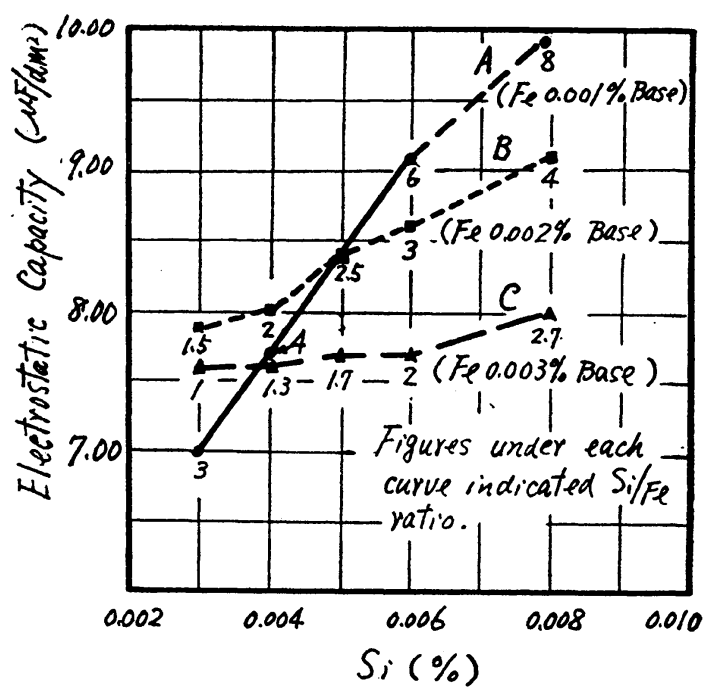

Fig. 2 Fffect of $\mathrm{Si}$

1,000 cycle にて静電容量を測定した。

尚その装置及び結線は第 2.3 報2，3）に示したもの と同じである。

\section{4. 試 駼 結 果}

\section{1 静電容量に及ぼす Fe の影響}

Fig.1 にその結果を示したが A 曲線で判るように99. $992 \% \mathrm{Al}(0.002 \% \mathrm{Fe}, 0.005 \% \mathrm{Si}, 0.001 \% \mathrm{Cu}) に \mathrm{Fe}$ 含 有量を 0.003〜0.006\%の範囲に添加した場 合その静電 容量は予想に反して増加せず $\mathrm{Fe}$ の添加に従つて静電容 量は低下している。 $\mathrm{B}$ 曲線は $\mathrm{Si} / \mathrm{Fe}$ 比を示すものであ るが、 $\mathrm{Fe}$ の增加は $\mathrm{Si} / \mathrm{Fe}$ 比の低下であつて $\mathrm{Si} / \mathrm{Fe}$ 比 の高い程静電容量は高いといえる。因に市販の 99. 99\% $\mathrm{Al}$ に $\mathrm{Fe}$ を 0.002〜0.004\% 添加されている。

\section{2 静雷容㽬に及ぼす Si の影響}

Fig. 2 にその結果を示したが、A 曲線は Fe 0.001\%

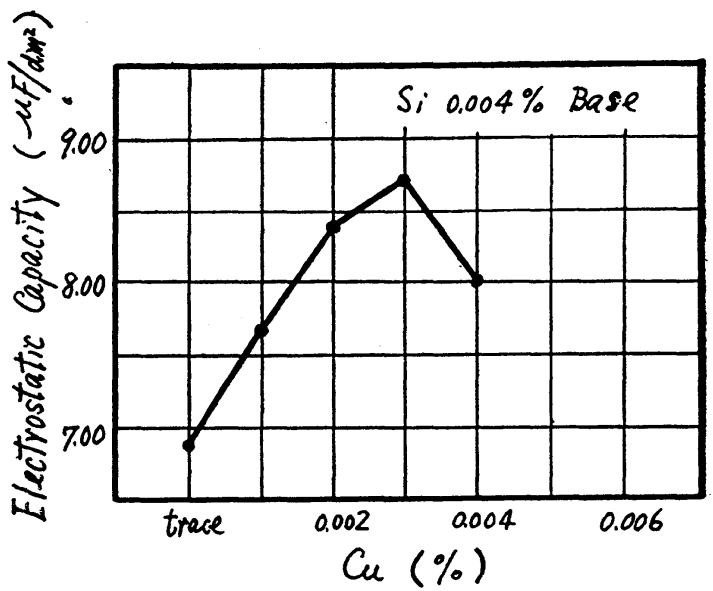

Fig. 3 Effect of $\mathrm{Cu}$. 
Fig. 4 Microstructures of $99.99 \%$ Al Foil adding $\mathrm{Fe}(\times 120 \times 2 / 3)$

(Annealed at $300^{\circ} \mathrm{C}$ for $1 \mathrm{hr}$ )

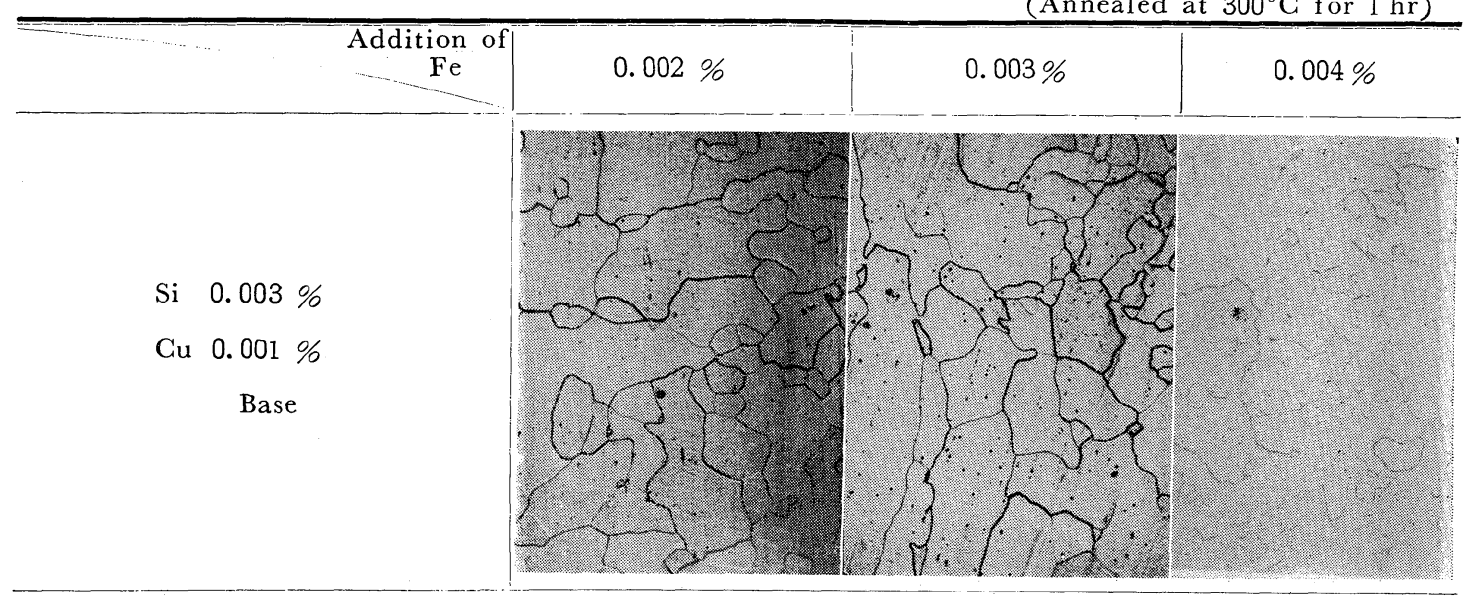

Fig. 5 Microsructures of $99.99 \%$ Al Foil adding $\mathrm{Si}(\times 120 \times 2 / 3)$

Addition

(Annealed at $300^{\circ} \mathrm{C}$ for $1 \mathrm{hr}$ )

\begin{tabular}{r|c|c}
\hline $\begin{array}{c}\text { Addition } \\
\text { of } \mathrm{Si}\end{array}$ & $0.004 \%$ & $0.006 \%$ \\
\hline
\end{tabular}

Fe $0.001 \%$

Base

Fe $0.002 \%$

Base
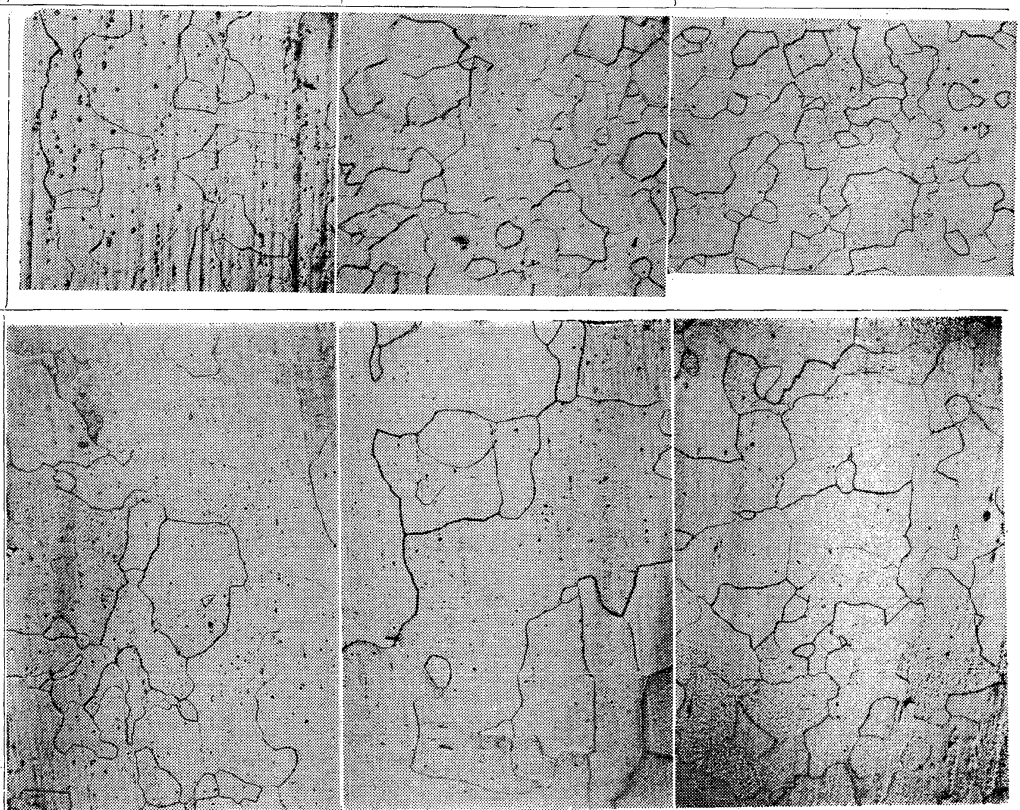

Fe $0.003 \%$

Base
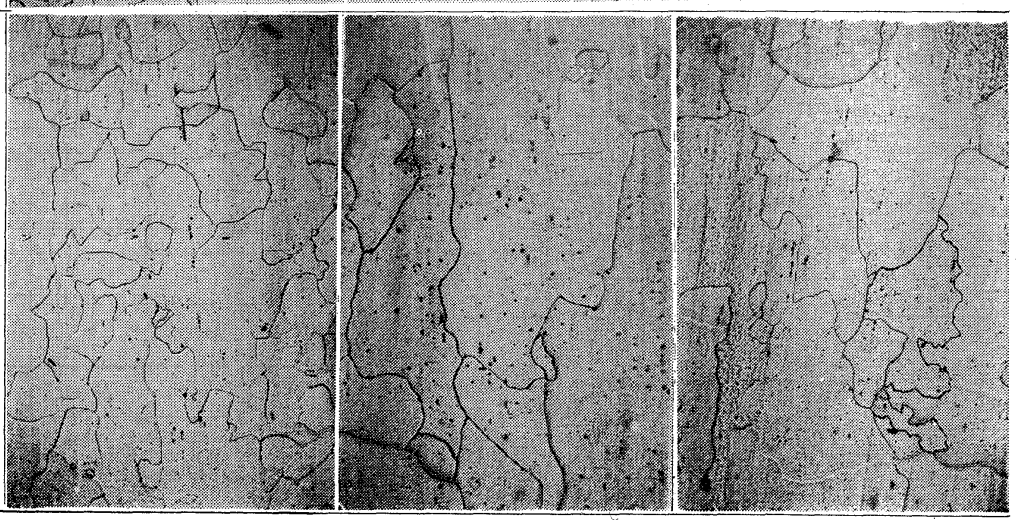
Fig. 6 Microstructures of $99.99 \%$ Al Foil Adding $\mathrm{Cu}(\times 120 \times 2 / 3)$

(Annealed at $300^{\circ} \mathrm{C}$ for $1 \mathrm{hr}$ )

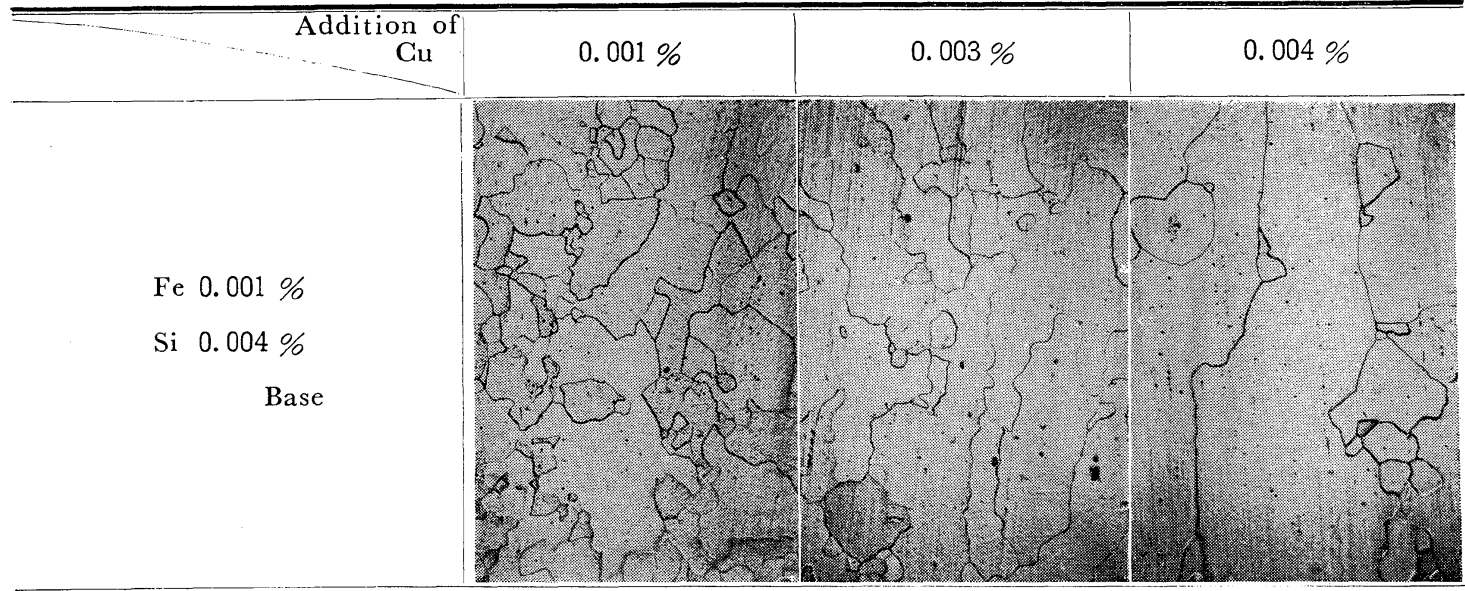

Base のものに、B, $\mathrm{G}$ 曲線はそれぞれ $\mathrm{Fe} 0.002 \%$ 及び $0.003 \%$ Base のものにSi を 0.004〜0.008\%の範囲に添 加した場合の静電容量の変化を示している。即ち Fe 0. 001\% Base のものに Si を0.006〜0.008\% 添加した場 合に最高の静電容量のものが得られることが判つた。 $\mathrm{Fe}$ 0.002\% Base のものでも Si を 0.008\% 添加した ものでは可成の高静電容量が得られるけれども Fe 0.003 $\%$ Base のものに Si を 0.008\%迄添加しても殆ど影響 はない。

従つてこの実験でも $\mathrm{Si} / \mathrm{Fe}$ 比が重要な因子をなして いるようで $\mathrm{Si} / \mathrm{Fe}$ の比の大きい成分のものが高静電容 量を得るのに好ましい。尚 $\mathrm{Fe}$ は既報の如く化成性能と しては有害成分であるのでなるべく低い方が望ましいの で Fe を $0.001 \%$ 以下とし化成性能に無害な Siを 0.008 \%以上添加したものが最も優秀な電解コンデンサー陽極 用材料であるといえる。

\section{3 静電容壘に及ぼす Cu の影晦}

Fig.3 にその結果を示したが 99.995\%Al（Fe 0.001
\%、Si 0.004\%、Gu tr. ) に Cuを0.001〜0.004\%の 範囲に添加した場合で $\mathrm{Cu} 0.003 \%$ 汽は静電容量は高 くなるが $0.004 \%$ では低下しているので $\mathrm{Cu}$ の添加は $0.002 \sim 0.003 \%$ が好ましい。

\section{4 再結晶粒度に及ぼす影響}

99. $99 \% \mathrm{Al}$ に $\mathrm{Fe}, \mathrm{Si}$ 及び $\mathrm{Cu}$ をそれぞれ0.002〜0. 004\%、0.004 0.008\% 及び 0.001〜0.004\% 範团添加 した顕微鏡写真を Fig. 4,5,6に示す、Fe の添加の再 結晶粒度に及ぼす影響は Fig. 4 に示す通りで Fe を0. 002\%添加すれば可成り再結晶粒子は小さくなつており、 0.004\% 添加すれば微細粒子になる。

Si の添加の場合にも Fig. 5 で判るように Si の增加 と共に粒子は小さくなる傾向は見られるが必しも同一傾 向ではなく、Fe 0.003\% Base のものでは逆の結果が 得られている。Fe 0.001\%及び Fe 0.002\% Base のも ので、Si $0.008 \%$ 添加したものが比較的微細粒子となつ ている。然し 99.99\% Al の再結晶粒子は不均一である のが通例であるので場所によつて粒子の大小の差があ

Table 2 Chemical Compositions of Commercial Super-purity Aluminium Foils for Electrolytic Condenser

\begin{tabular}{|c|c|c|c|c|c|c|c|}
\hline \multirow{2}{*}{ Kind } & \multicolumn{6}{|c|}{ Chemical composition (\%) } & \\
\hline & $\mathrm{Si}$ & $\mathrm{Fe}$ & $\mathrm{Cu}$ & $\mathrm{Mg}$ & $\mathrm{Mn}, \mathrm{Zn}, \mathrm{Ti}$ & $\mathrm{Al}$ & \\
\hline $99.99 \%$ & $\begin{array}{l}0.005 \\
0.004 \\
0.004 \\
0.005\end{array}$ & $\begin{array}{l}0.002 \\
0.002 \\
0.003 \\
0.002\end{array}$ & $\begin{array}{l}0.002 \\
0.002 \\
0.001 \\
0.003\end{array}$ & $\begin{array}{l}0 \\
0 \\
0 \\
0\end{array}$ & $\begin{array}{l}\text { tr. } \\
\text { tr. } \\
\text { tr. } \\
\text { tr. }\end{array}$ & $\begin{array}{l}99.991 \\
99.992 \\
99.992 \\
99.990\end{array}$ & \\
\hline Al foil & \multicolumn{2}{|c|}{$(\mathrm{Si}+\mathrm{Fe}+\mathrm{Cu})$} & $\cdots<0.01$ & - & tr. & $>99.99$ & JIS No. 1 \\
\hline \multirow[t]{2}{*}{$\begin{array}{l}99.9 \% \\
\text { Al foil }\end{array}$} & $\begin{array}{l}0.025 \\
0.020 \\
0.030 \\
0.020\end{array}$ & $\begin{array}{l}0.020 \\
0.018 \\
0.022 \\
0.015\end{array}$ & $\begin{array}{l}0.005 \\
0.004 \\
0.005 \\
0.004\end{array}$ & $\begin{array}{l}0 \\
0 \\
0 \\
0\end{array}$ & $\begin{array}{l}\text { tr. } \\
\text { tr. } \\
\text { tr. } \\
\text { tt. }\end{array}$ & $\begin{array}{l}99.950 \\
99.958 \\
99.943 \\
99.961\end{array}$ & \\
\hline & $<0.04$ & $<0.03$ & $<0.04$ & - & - & & JIS No.2 \\
\hline $\begin{array}{l}99.99 \% \text { Al-Mg } \\
\text { Alloy foil }\end{array}$ & $\begin{array}{l}0.002 \\
0.003 \\
0.001 \\
0.002\end{array}$ & $\begin{array}{l}0.001 \\
0.001 \\
0.001 \\
0.002\end{array}$ & $\begin{array}{l}0.001 \\
0.001 \\
0.001 \\
0.001\end{array}$ & $\begin{array}{l}0.025 \\
0.028 \\
0.027 \\
0.026\end{array}$ & $\begin{array}{l}\text { tr. } \\
\text { tr. } \\
\text { tr. } \\
\text { tr. }\end{array}$ & $\begin{array}{l}99.971 \\
99.967 \\
99.970 \\
99.967\end{array}$ & $\begin{array}{l}\text { Patent of } \\
\text { Toyo Al Co. }\end{array}$ \\
\hline
\end{tabular}


Fig. 7 Microstructures of $99.99 \%$ Al Foils with Various Purities (Annealed at $300^{\circ} \mathrm{C}$ for $1 \mathrm{hr}$ )

\begin{tabular}{|c|c|c|c|c|c|}
\hline & $\begin{array}{c}\text { Al } \\
(\%)\end{array}$ & \begin{tabular}{c|}
$\mathrm{Si}$ \\
$(\%)$
\end{tabular} & $\begin{array}{l}\mathrm{Fe} \\
(\%)\end{array}$ & $\begin{array}{c}\mathrm{Cu} \\
(\%)\end{array}$ & 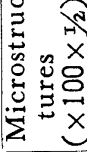 \\
\hline \multirow{2}{*}{$\begin{array}{l}\text { Not used for } \\
\text { electrolytic } \\
\text { condenser }\end{array}$} & 99.995 & 0.003 & 0.001 & 0.001 & A \\
\hline & 99.993 & 0.004 & 0.001 & 0.001 & B \\
\hline \multirow{2}{*}{$\begin{array}{l}\text { Commercial } \\
99.99 \% \text { Al foil } \\
\text { for electrolytic } \\
\text { condenser }\end{array}$} & 99.991 & 0.005 & 0.002 & 0.002 & $\mathrm{C}$ \\
\hline & 99.990 & 0.005 & 0.002 & 0.003 & D \\
\hline $\begin{array}{l}\text { New product } \\
\text { for electrolytic } \\
\text { condenser }\end{array}$ & 99.990 & 0.008 & 0.001 & 0.001 & $\mathrm{E}$ \\
\hline $\begin{array}{l}\text { Commercial } \\
99.9 \% \text { Al foil } \\
\text { for electrolytic } \\
\text { condenser }\end{array}$ & 99.959 & 0.022 & 0.016 & 0.003 & $\mathrm{~F}$ \\
\hline
\end{tabular}

り、これらの写真のみでは判断することは出来ないけれ ども、Si を添加する程粒子は小さくなる傾向はあると 考元て差支えない。

次に $\mathrm{Cu}$ の添加の影響は Fig. 6 に示す如く添加と共 に粒子は若干大きくなるようである。

\section{5 市販の 99.99\% Al の成分と再結晶組織}

Table 2 に市販されている 99.99\%Al，99.9\%AI 及び $\mathrm{Mg}$ 入の $99.99 \% \mathrm{AI}$ 䇴の化学成分を示し、また Fig. 7 にこれらの顕微鏡写真を掲げたが、99.993\%以上の高品 位のものは粒子が著しく粗大であつて実用にならず、Fe を約 $0.002 \% 、 \mathrm{Si}$ を約 $0.005 \%$ 添加した 99.990〜99. $991 \%$ 純度のものが現在実用されており、最終焼鈍を適 正に行えば 99.9\% $\mathrm{Al}$ の再結晶粒度に匹敵する比較的微 細な粒子のものが得られている。

尚 $\mathrm{Fe}$ を $0.001 \%$ とし Si $0.008 \%$ 添加したものは 99.9\% Al と同程度の微細粒子がられることが判る。

\section{5. 考察}

$\mathrm{Si}, \mathrm{Fe}, \mathrm{Cu}$ の高純度アルミの腐食性に及ぼす研究に 関してはこれ迄に多数の文献はあるが何れもその添加量 が $0.010 \%$ 以であつて著者等の問題にしている 0.010 \%未満の極微量の影響に関しては詳細に検討されていな いし、その腐食試験の方法も単なる腐食であつて電解腐 食方法による実験は皆無である。従つて電解コンデンサ 一陽極材料としての静電容量に関する研究は海外でも殆 んど発表されていないので、今後更にこれ等の微量不純 物の電解腐食に及ほす影響を詳細に組織的に研究しない とその腐食の機構なり高静電容量の出しうる原因に関し ては今の処充分に説明することは出来ない。

ただ塩酸腐食に対し $\mathrm{Si}, \mathrm{Fe}, \mathrm{Cu}$ 何れもその腐食を增

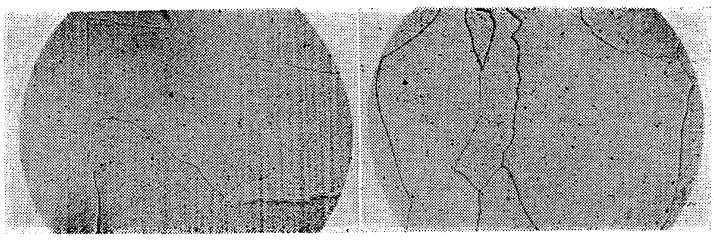

(A)

(B)

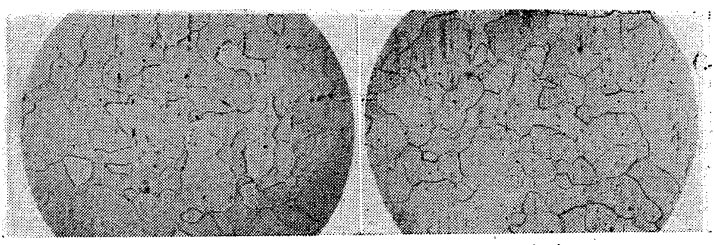

(C)

(D)

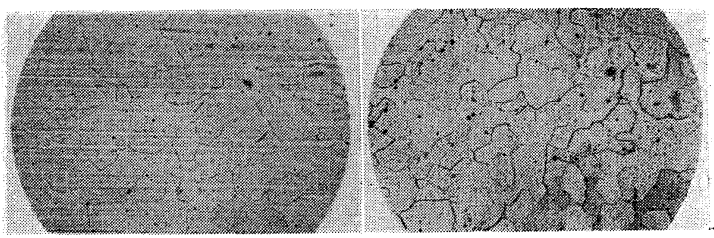

(E)

(F)

す傾向のあることは正しいと考えられるが、これ等の内 で普通の腐食法では $\mathrm{Cu}$ が最も腐食の効果があり $\mathrm{Fe}$ の 10倍位であるといわれている。しかし単に全面腐食を促 進するのでは電解コンデンサー陽極板の場合にはその静 電容量を増すことは出来難く、無数の小さいしかも深い 穿孔腐食が強電流下に於て行われてその表面積を拡大し なければならない。従つて再結晶粒子の微細なものほど その多い粒界は深く腐食され易く高静電容量のものが得 られ易い筈であるが、更に結晶粒内のマトリックスの腐 食も行われ好高倍率のものが得られないことは明かで ある。

$\mathrm{Fe}$ の添加の場合には明かに 結晶粒は明細になるし又 微細な $\mathrm{FeAl}_{3}$ 化合物の析出があるのでその化合物附近 が深く腐食されるであ万うから表面積は拡大されるもの と考兄られる。併し $\mathrm{Fe} 0.003 \%$ 以上になると恐らくよ り大きい形状の化合が多くなつて電解腐食中に $\mathrm{Fe} \mathrm{Al}_{3}$ 化合物が表面から脱落現象を起して比較的に大きい径の 浅い孔数が増して来て、無数の小径の深い穿孔状態の ものよりも全表面積は拡大しないのではないかと考元ら れる。

Si の添加の場合は $0.008 \%$ では $300^{\circ} \mathrm{G}$ 焼鈍に於て は勿論固溶化の状態であるが、徐冷によつてその一部は 析出しているかも知れない。即ち $200^{\circ} \mathrm{C}$ での $\mathrm{Si}$ の固 溶限は $0.05 \%$ といわれているが常温での固溶限ははつ きり判つていないし $\mathrm{Fe}$ と共存の場合には当然に $\mathrm{Si}$ の 固溶限は減少するであろうから $0.008 \%$ \% $\mathrm{Si}$ でも一部 は析出状態にあるものと考えられる。従つて $\mathrm{Fe} 0.001$ \% Base のものでは Si の一部は超顕微鏡的な析出状態 
にあるが、 $\mathrm{Fe}$ 0.003\% Base になると Al-Fe-Si 化合物 が增加して来て $\mathrm{Si}$ が化合物に喰われて $\mathrm{Si}$ の析出が減 少するのではなかろうか。

$\mathrm{Si} / \mathrm{Fe}$ 比の大なるほど静電容量が增加する現象も $\mathrm{Fe}$ 0.001 乃至 $0.002 \%$ 範团のことであつて $\mathrm{Fe} 0.003 \%$ 以上では殆んど無影響であるから Si の添加の効果は結 晶粒子若干微細にする効果よりも結晶粒内筷食を促進 する効果があるものと考光られる。 $\mathrm{Si}$ 添加による表面 積の拡大の理論に関しては今のところこれ以上の説明は 出来ないので今後の研究を待つ外ない。

次に $\mathrm{Cu}$ の添加はその結晶粒子をむしろ粗大にする 傾向が見られるが静電容量は明かに高くなるので表面積 の拡大は粗界の腐食よりも粒内腐食の方の影響が大きい ことを暗示している。従つて $\mathrm{Cu}$ の增加は粒内腐食を 促進するので好ましいが $0.004 \%$ の添加では静電容量 が逆に低下しているのは実験の間違いか或いは何にか原 因があるか判らない。併し結晶粒子の粗大化による粒界 腐食の減少によるものと考える外ない。

以上要するに $\mathrm{Si}, \mathrm{Fe}, \mathrm{Cu}$ を微量添加した場合何れも 99.99\% Al の應食を促進することは事実であるが電解 腐食の場合の简食の機情なり腐食孔の特性なりは全く不 明の点が多く今後の研究に期待する外ない。

\section{6. 結 言}

99. 99\%AI を使用して出来るだけ大容量小型の電解コ ンデンサーを作るためには電解腐食による表面積拡大率 の大きい材料を使用せるね゙はなず、しか子漏洩電流の少
いものが望ましいことからして不純分としての $\mathrm{Fe}$ は出 来る限り低くし、Si を含有量の数倍以上を添加し $\mathrm{Si} / \mathrm{Fe}$ 比をなるべく大きくした高純度アルミ箔が最も優れた陽 極用材料であるといえる。従来は結晶粒子を微細にして 静電容量を高める方法が考兄られていたので化成性能に は明かに有害である、Fe を特に 0.002 0.004\%添加 したものが市販されているが、今後は本研究によつて、 $\mathrm{Fe} 0.003 \%$ 以上の添加は必ずしも静電容量を増加しな く返つて低下さすことが判明したので Fe は精製アル ミ地金に含有される0.001\%以下のままとし化成性能に 無害である。 $\mathrm{Si}$ を含有 $\mathrm{Fe}$ 分の数倍以上添加した材料 を使用すべきであり、更に $\mathrm{Cu}$ を $0.002 〜 0.003 \%$ 添加 したものが一層に優れた陽極材料であるといえる。

現行 JIS 規格第一種高純度アルミ箔 (99.99\%) の純 度は 99.99\%以上と規定されているが Fe 含有量が0.001 \%以下の場合には、必ずしも $99.990 \%$ 以上に限定する 必要もなく、アルミ純度としては 99.970〜99.991\%の 範围が好ましく、又その含有不純物としては Si 0.007〜 $0.009 \% 、 \mathrm{Fe} 0.001 \%$ 以下 $\mathrm{Cu} 0.001 \sim 0.003 \%$ に配合 したものが化成性能に最も優れ且つ高静電容量高耐圧性 の電解コンデンサー陽極用材料である。

\section{文献}

1）川帠、中村、本誌 No.5 (1952)、121

2) 川孟、中村、西坂、本誌 No.17 (1955)、75

3) 中村、西坂、本誌 No. 20 (1956)、58

\section{軽金属研究会日誌}

31.9.13 軽金属研究編集打合会 10持、於軽協、出庸 者11名。

(1)軽金属研究会誌「軽金属」の編集方針強化 について、(2)軽金属誌の発刊日の変更につい て、(3掲载内容の充実について（論説、解説、 '研究報告、応用報告、座談会記録、講座、特 許公告、文献紹介)、(4)編集委員の委嘱と今後 の活動方針について

31.10. 4 軽金属研究会編集委員会 14時、於軽協、出 席者 9 名。

(1)軽金属第 2 号編集方針について、(2)研究馀 文の査読分担、查読方法について、(3)見学工 場について、(4)その他。

31.10 .15 軽金属研究会第11回秋季大会案内状会員全員 に発送。

31.10.25 第 1 回軽金属蛍委員会 13 時30分、於軽協、 出席者安田会長他委員関係者 8 名。 昭和31年度軽金属賞受賞者選衡要領(案)につ いて、(2)本年度受賞者定数について、(3)受賞 候補者追加推蔍について、(4)受賞者決定方法 の細目について、

31.10 .26 軽金属研究会編集打合会 17時、於軽協、出 席者6名。

(1)秋季大会開催細目について協議。

31.10 .27 昭和31年度軽金属賞受賞候補者投票依頼（軽 金属賞委員31名に依頼）

31.11. 9 第 2 回軽金属賞委員会 13時30分、於軽協、 出席者 10 名

(1)昭和31年度軽金属賞受賞候補者選衡。

31.11 .10 軽金属研究会編集委員会 13時30分、於軽 協、出席者11名。

(1)軽金属誌No.21の編集校正、(2)軽金属研究 会秋季大会運用方針細目につき検討。

31.11 .14 軽金属誌 No.21 発刊。 